Volume 8 Issue 1

Californian Journal of Health Promotion, 2010

Table of Contents

Content

CJHP Editorial Board

$\underline{\text { Pages }}$

Table of Contents

i-ii

Editorial

iii-iv

One more step to profession unity: Is it possible to

v-viii

bring the professional health education organizations together?

James F. McKenzie and Jagdish Khubchandani

\title{
RESEARCH AND THEORY
}

Best Practices for Telemedicine Programs

01-09

Lois A. Ritter, Tessa R. Robinette, and John Cofano

Safer Sexual Practices and HIV Screening Behavior

$\underline{10-21}$ among Rural California American Indians

Felicia S. Hodge and Karabi Sinha

What Type of Weight Loss Program do Postpartum

$\underline{22-31}$ Women Want? Treatment Preferences of Postpartum Women in Two Community Settings

Suzanne Phelan, Katelyn Smith, John-Mark Steele, Dawn

Wilt, Sally Ames, and Linda McClure

Children's Choice of Wii Sports Games and Energy Expenditure

Bryan L. Haddock, Shannon R. Siegel, and Linda D. Wilkin

Enhancing wellness by therapeutic lifestyle change: Does

$\underline{40-45}$ cost determine program commitment?

Shveta Sanghani, Alexis Deavenport, Patti Herring, S. Eric Anderson, Ernie Medina, and Sanam Kazemi

A Mixed-Method Evaluation of a College Student Fitness Program Using the RE-AIM Framework Michelle L. Bartlett and Sam J. Zizzi 
Content

The Effects of an Adolescent Asthma Education

60-71

Intervention on Knowledge, Intention, Behavior, Self-

Efficacy and Self-Consciousness

Kara Zografos, Helen Hopp Marshak, David T. Dyjack and

Christine Neish

The Voices of Native Hawaiian Women: Perceptions, Responses and Needs Regarding Intimate Partner

Violence

Mary F. Oneha, Lois Magnussen and Jan Shoultz

\section{WORK BY GRADUATE STUDENTS}

The Ever Evolving Concept of a New Public Health: Book

Review

Nancy Shehadeh

We are Family: Family History of Diabetes among

88-97 African Americans its Association to Perceived Severity, Knowledge of Risk Factors, and Physical Activity Levels

Alexander Omolafe, Michele Mouttapa, Shari McMahan, and Sora Park Tanjasiri 